December 2013

\title{
The Female Librarian in Film: Has the Image Changed in 60 Years?
}

Julia A. Wells

San Jose State University School of Library and Information Science, fraserwells@telus.net

Follow this and additional works at: https://scholarworks.sjsu.edu/ischoolsrj

Part of the Library and Information Science Commons

\section{Acknowledgements}

This paper originated in my LIBR 200 Info. and Society class (Fall 2012). Thank you to Professor Debbie Hansen for her support and encouragement throughout the class.

\section{Recommended Citation}

Wells, J. A. (2013). The Female Librarian in Film: Has the Image Changed in 60 Years?. School of Information Student Research Journal, 3(2). https://doi.org/10.31979/2575-2499.030202 Retrieved from https://scholarworks.sjsu.edu/ischoolsrj/vol3/iss2/2

This article is brought to you by the open access Journals at SJSU ScholarWorks. It has been accepted for inclusion in School of Information Student Research Journal by an authorized administrator of SJSU ScholarWorks. For more information, please contact scholarworks@sjsu.edu. 


\title{
The Female Librarian in Film: Has the Image Changed in 60 Years?
}

\begin{abstract}
The stereotypical image of the female librarian as an uptight spinster has prevailed in popular culture. This paper examines the portrayal of the librarian stereotype in movies from two different eras: the 1940 s/1950s and the 2000s. The historical antecedents, social and economic status of women are examined, and the influence of computers and technology in the library is considered. Common traits that typify the film librarian, along with the inclusions of computers in the library, are identified and analyzed. Approaches to combatting the stereotypes are discussed and applied to the movies in order to discover any progression of the image in 60 years. It is concluded that while there has been some progress in the characterization of librarians in movies, overall there has been little change in 60 years.
\end{abstract}

\section{Keywords}

librarian, stereotype, movies, traits, librarian stereotype, cinematic image

\section{Acknowledgements}

This paper originated in my LIBR 200 Info. and Society class (Fall 2012). Thank you to Professor Debbie Hansen for her support and encouragement throughout the class.

\section{About Author}

Julia Wells is a graduate student in the MLIS program at SJSU School of Library \& Information Science. She received her BA in Psychology and Women's Studies from McGill University, in Montreal, Canada. 


\section{Introduction}

Two women are talking to each other in a library. The first is dressed conservatively: high collar, modest below-the-knee skirt, comfortable shoes. Her hair is in a bun and she is wearing glasses. Her companion wears a form-fitting blouse, jeans and funky boots. Her hair falls loosely around her face. If asked to point out the librarian, most people would choose the first woman. The prevailing stereotype of the librarian (old, hair in a bun, glasses, conservative dress, unmarried) is so ingrained in the North American consciousness that throughout the past century, the image of librarians in popular media, particularly in film, has changed very little (Tevis \& Tevis, 2005).

This paper will address the question of whether or not the popular librarian image, as depicted in the medium of film, has changed in 60 years, and if it reflects the shift in the roles of women and librarianship. With the obsolescence of card catalogues and rubber stamps, and the explosion of technology within the field of library science, academics have suggested that perhaps the image of the librarian will change from the boring, monotonous task-oriented drudge, to the dynamic sharer of technological knowledge (Adams, 2000; Stevens, 2001; Tevis \& Tevis, 2005). Taking into account the socio-historical context of the earlier era movies and the librarian image they portray, this study will compare the image of the female librarian found in the earlier movies to the more recent films, book-ended by the 60 year span, in order to discover if the academic advice has taken hold. Has the representation of the librarian changed to depict a more positive image of the librarian? Has the image been appropriated and "owned" by the movie librarian? Or are movie-goers still watching the same old stereotype on the silver screen?

How does the consistent inclusion of this negative image affect the librarian profession? The word "stereotype" is defined as "a preconceived, standardized, and oversimplified impression of the characteristics which typify a person" (Barber, 1998). According to Radford and Radford, the relentless negative stereotype "ultimately constricts the power and economic status of a gendered profession - librarianship" (2003, p. 59). This notion of a stereotype affecting the economic status of a profession is not a new one. In a 1960 article, Leigh and Sewny state that "the popular image of the librarian has direct effect upon the degree of support given to his library in book funds, salaries, housing, [and] equipment" (p. 2089). Because of the obvious impact of these negative portrayals on the librarian profession, three different questions have been examined in the scholarly and professional discourse: (a) How is the stereotypical image of the librarian depicted and what are the historical antecedents of this image? (b) Does this popular image reflect the actual librarians in America? and, (c) How do we change the negative aspects of the stereotype in popular culture? (Adams, 2000).

There have been in-depth studies of the librarian character in movies throughout the $20^{\text {th }}$ century (Walker \& Lawson, 1993; Tevis \& Tevis, 2005), but there has been limited academic discourse of the librarian image in films from 2000 to the present. In a 2005 study, Threatt looked at the librarian image in six movies, noting only if they conformed to the Myers-Briggs list of personality traits (Threatt, 2005). Tancheva (2005) studied three movies and the semiotic meanings of the library and librarian depicted in each. By comparing the librarian image in 
twelve movies from either end of a 60 year span, my study strives to demonstrate the extent of the evolving librarian image, and ultimately how little it has changed in 60 years.

\section{Historical Antecedents and Literature Review}

In the early part of the twentieth century, when young unmarried women were joining the workforce in greater numbers, librarianship was one of the few occupations deemed suitable for women. What began as a male-dominated field became mostly the purview of women, so that by $1910,78 \%$ of librarians were women (Newmyer, 1976). Because only single women were permitted to work at this time, the image of the librarian as spinster was born. Newmyer wrote that it was "scientific management... which created and perpetuated a submissive, dependent, spinsterish librarian image of such strength and durability" (1976, p. 48). In 1946, William Form conducted a study to identify whether or not the popular image of a librarian matched with the librarian personality. He asked the question, "What kind of people are librarians, in your estimation?" (p. 852). He found that "the negative personal and social qualities attributed to librarians outweigh the positive and neutral attributes" (Form, 1946, p. 852). The weakness in this study was the lack of standardization in asking the survey question. For example, 50 different students asked laypeople the survey question, with probably 50 different ways of asking and responding.

In a guest editorial in an issue of Saturday Review, Howard Mumford Jones wrote that a "librarian too often resembles a head-waiter showing one to a table in a large restaurant and too little resembles an artist having profound and passionate views of life, death and immortality" (1960, p. 53). By the 1940s and 1950s, with more and more women entering the workforce and with women still being pressured to retain their traditional female roles, film and media continued to fully embrace the delineation of male and female roles (Ferguson, 1991). As a result, in movies from this era, the main goal of the so-called old maid (at 30 years of age) was to be engaged or married by the end of the story.

Over the last half-century, theories have been postulated about the reasons for the negative characteristics of the librarian stereotype: i.e., failure to differentiate between librarians and library workers (Leigh \& Sewny, 1960), or the relationship between power, knowledge and fear (Radford \& Radford, 1997). However, there is agreement that popular culture, including media, plays a significant role in creating and fostering the images we all have come to associate with librarians (Stout, 2004; Tevis \& Tevis, 2005). The common thread throughout the literature seems to be the desire to find a "solution" to the stereotype: how do we possibly change the commonly held view of librarians?

In earlier studies, the advice for real-life librarians ranges from the suggestion to show more enthusiasm for the library patron (Form, 1946), to show more enthusiasm for the content of books rather than for the shelving of them (Jones, 1960). In a book called Revolting Librarians, the advice is to "meditate... smile at the patrons... [and] bring in goodies" (West \& Katz, 1972, p. 20). In more recent studies, three different ways to approach the movie and real life dilemma are offered: (a) reverse the stereotype, (b) substitute the image of negative qualities with positive, or (c) tackle the stereotype from within, or "own" it (Adams, 2000; Duncan, 2004; Radford \& Radford, 2003; Wallace, 1989). It seems that the greatest divergence in thought on how to 
combat the prevailing stereotype is that some scholars believe that we should change the image, and ourselves, to a more positive presentation (Duncan, 2004; Wallace, 1989), while others believe that we need to appropriate the image and make it our own (Adams, 2000; Radford \& Radford, 2003). Stout writes that "breaking through old stereotypes by self-parody...[is] a critical phase of assimilation that usually results in re-emerging with greater strength" (Stout, 2004).

\section{Methodology}

For this paper, the movies were randomly chosen as samples from two specific time periods, on either side of a 60 year time span. In order to include similar genres for analysis, all were English-language, set in North America, non-science fiction, and non-animated. The six films from the 1940s and 1950s were The Philadelphia Story (1940), Citizen Kane (1941), The Big Sleep (1946), It's a Wonderful Life (1946), Good News (1947) and Desk Set (1957). The six films from the 2000s were: Tomcats (2001), The Emperor's Club (2002), The Station Agent (2003), Because of Winn-Dixie (2005), I Love You, Beth Cooper (2009) and Arthur (2011). The following physical characteristics of the librarian character were compared: (a) age, (b) hairstyle, (c) clothing, (d) presence of glasses, and (e) marital status. The demeanor of the character was also noted. For example, was she stern ("shhh!"), or friendly? Additionally, in the modern films, the inclusion of computers as a part of the library environment was examined. Although there are also stereotypes of the male librarian in popular culture, this paper will analyze only the movies in which the librarian character is female, while taking into account the changing roles of women in society in the 60 year interval.

\section{0s and 1950s Movies}

The first film analyzed was The Philadelphia Story (1940), starring Cary Grant, Katherine Hepburn and James Stewart. Hepburn plays Tracy Lord, a rich socialite. Two years after her divorce from Grant's character, C. K. Dexter Haven, Tracy is about to remarry. Haven is now a tabloid newspaper editor who solicits the journalist Mike Connor (played by Stewart) to dig up some dirt on Tracy Lord. As this movie is set in a time before Google and Twitter, Mike makes a trip to the local public library to find out more about the Lord family history. The librarian (un-credited, played by Hilda Plowright) is a woman in her 40s or 50s, wears her hair in a bun, and has on a conservative dress with a high collar. She says things like, "What is thee wish?" and "If thee will consult with my colleague in there" (Mankiewicz, 1940). Mike finds Tracy in another part of the library reading a book that he has written. As the two start chatting about the book, the librarian puts her finger up and says, "Shh, shh". The librarian stereotype is fully embraced in this earliest movie from the time period.

In the next movie from this era, Citizen Kane (1941), an eccentric wealthy industrialist, Charles Foster Kane (played by Orson Welles), dies with one last word on his lips: "Rosebud." Journalists have been dispatched to the Thatcher Memorial Library to read the private diary of Walter Parks Thatcher, Kane's childhood guardian, to see if the word "Rosebud" had any special 
significance in Kane's life. We find the librarian, Miss Anderson (played by Georgia Backus), a very formidable character indeed. She presides over an imposing, cavernous hall that echoes with her every word. She looks to be in her 30s or 40s, with short slicked-back hair, and wears a severe black suit, a tie, and glasses. She is unmarried. She is extremely dismissive, talking over the journalist and ignoring what he says. This librarian certainly embodies the stereotype that William Form found in his survey of college students in 1946. In describing their idea of a

librarian, the students' answers could have been pulled directly from a viewing of Citizen Kane: "librarians are... ignorant, impatient, pretentious, old-maidish, and introvertic" (Form, 1946, p. 854).

The 1946 movie The Big Sleep stars Humphrey Bogart as private detective Philip Marlowe and Lauren Bacall as the eldest daughter of a wealthy retired general who is being blackmailed. Marlowe stops in at the Hollywood Public Library to research titles of first edition books so that he can trick a local bookseller into giving him information. There are two librarians in this library. The secondary librarian who can be seen in the background is 30ish and wears her hair in a bun. The main librarian is in her 20s or 30s, has her blonde hair in a bun, wears glasses, is unmarried (no wedding ring), and primly dressed with a wide white collar. She asks Marlowe if he has found what he wanted, and then says, "You don't look like a man who'd be interested in first editions" (Warner, 1946). Marlowe obviously takes this as an insult because he answers, "I collect blondes in bottles too" (Warner, 1946), and thus manages to return the insult. This librarian conforms to the prevailing stereotype of the time as "prim, austere... superficial, petty, tyrannical technicians who yearn for the status of... doctors, lawyers..." (Powell, 1959, p. 17).

Another negative portrayal of a librarian from this era can be found in It's a Wonderful Life (1946). A guardian angel shows a suicidal George Bailey (played by James Stewart) what the world would have been like if he had never been born. He is brought to the Potterville Public Library where Mary Hatch (played by Donna Reed) is locking up the library for the night. Mary would have been married to George if he had been born, but alas, she remained unmarried and so became a librarian. Her hair is in a bun, she wears a conservative suit with a masculine hat, and wears glasses. As she walks down the street she hugs her purse to her chest and looks unhappy and frightened. As the music swells, the audience is meant to think, "No! Not a librarian!" Mary is exactly what Ferguson describes as "physically unattractive, pitiful, irrational, queer and finally crazy” (as cited in Ferguson, 1991, p. 132).

Good News (1947) did not bring great news for the image of the librarian. This film is a lighthearted musical about a college football star, Tommy Marlowe (played by Peter Lawford). Tommy falls for his French tutor, Connie Lane (played by June Allyson), who also happens to be the assistant librarian at the college library. When Tommy asks Connie why she works in a library, she answers, "Oh, it helps pay my tuition, it's something called working your way through college" (Freed, 1947). So, the librarian in this movie seems to conform to the image of the unmarried woman who needs money. Connie is portrayed as sex-less when she first appears: while all the other girls are dressing for a sorority party, Connie is fixing the pipes and has her head under the sink. When she is in the library, Connie's appearance is mostly against type: no bun, no glasses, young and attractive, but she does wear a conservative dress (although one which sports fashionable polka dots). 
Interestingly, Connie is really just a student worker in the library. We see the real librarian in a scene where Connie is shouting out the window to the football team. The librarian is in her 60s, with a grey-haired bun, who says, "Shhh" at Connie. Also, as Connie dresses for the prom, she asks her friend, "How do I look?" Her friend answers, "You sure don't look like a librarian," and Connie says, "Oh, I don't feel like one" (Freed, 1947). This difference between the image of the library worker and actual librarians is interesting to note because Leigh and Sewny postulated that the main source of the negative image of the librarian is:

The failure of library users to see that not all the people who work in libraries are librarians; the greater visibility of desk assistants performing routine clerical duties in direct contact with patrons, compared with the librarians performing the more important and interesting professional tasks behind the scenes. (1960, p. 2090)

The irony is that Connie as the library worker is fresh, attractive and personable, while the librarian is stereotypically harsh and dowdy.

The last movie from this era, and the most positive portrayal of librarians, was Desk Set (1957). This iconic librarian movie stars Katherine Hepburn as the head librarian, Bunny Watson. It is set in the reference department of the "Federal Broadcasting Company" and features four librarians who are faced with the installation of a huge new computer, called EMERAC, that will "free the worker from routine and repetitive tasks" (Ephron, 1957). In many ways this movie breaks the mold of the prevailing librarian stereotype. The librarians sit at desks, trading jokes and answering quirky questions from unseen callers. True to the stereotype, all four women are single and talk about the desire to get married and how to catch a man. Three out of four are reaching "old maid" territory (over 30 years old). One of them comments on her single status: "You go along thinking you're not going to be alone any more, and then one day you realize it's all over, you're out of circulation" (Ephron, 1957). She then turns the image on its head by declaring, "When that day comes, we'll move in together and keep cats. I don't like cats, I like men and so do you" (Ephron, 1957). Although these librarians may conform to the image of the know-it-all librarian, they certainly subvert the stereotype with many witticisms. They also destroy the "shushing" librarian by being loud and funny, and whooping it up at the office Christmas party - - drinking and dancing. This portrayal runs contrary to the idea that librarians are "less likely to go to nightclubs than are receptionists or department-store buyers" (Jones, 1960, p. 34).

\section{0s Movies}

In addition to looking at the physical attributes and characterization of the librarians in this set of movies, the incorporation of technology in the portrayal of the profession was also noted. "In recent years, digital technology has transformed how librarians identify, collect, and organize information. Librarians are increasingly associating themselves with computers rather than books" (Adams, 2000, p. 287). With this in mind, the expectation would be that the portrayal of librarians in these recent films would reflect the changing technological environment of the library. 
The first movie analyzed was Tomcats (2001). This movie is a broad comedy about a group of men who made a bet in their twenties about who can stay unmarried the longest. Michael Delaney (played by Jerry O'Connell) decides to pick up the seriously repressed and mousy librarian, Jill (played by Heather Stephens), at the local public library. When she first appears in the library scene, there is nary a computer in sight, and she is carefully shelving books. Jill's hair is in a bun (with what looks suspiciously like a pencil sticking out of it). She wears glasses and a cardigan. This stereotype gets completely turned on its head, for broad comic effect, of course. Jill turns out to be a dominatrix who lives with her grandmother in a house resembling a sadomasochistic playground. She says things like, "One whack for every overdue book" (Garner, 2001). And, of course, the grandmother turns out to not only be a retired librarian (also clad in pearls and a bun), but is a dominatrix to boot! Besides the humor factor, this depiction does conform to the "sexy" repressed librarian image, serving to replace one broad stereotype with another: she is either virgin or whore, with nothing in between.

The Emperor's Club (2002) has a brief, but important, librarian scene in it. This movie is set in a private boys' school in which a contest, called the "Mr. Julius Caesar," is run every year. The boys compete in a series of quizzes to test their knowledge on various subjects. One of the boys, Sedgewick Bell (played by Emile Hirsch), goes to the school library to try to take out a popular book overnight. The librarian is hunched over a desk in a dimly lit library with no computers in sight. Miss Peters (played by Molly Regan) is unmarried, dressed conservatively with a high neckline, and wears a cardigan. Her hair is chin-length and is not in a bun, but she does wear glasses. She will not allow Sedgewick to take out the sought-after book overnight. She displays no humor or warmth. Sedgewick tries to flatter her hairstyle, by saying, "Is that new?" She responds, "I've had it since 1958" (Abraham, 2002). Radford and Radford suggested that librarians could be seen as fearsome because they are the "guardian[s] of rationality" (1997, p. 259). This fear can be "managed, defused, and disguised [because] beneath the stern exterior, there is nothing to fear: there is only a woman" (Radford \& Radford, 1997, p. 261). When Sedgewick tries to flatter Miss Peters, perhaps he is managing the inherent fear found in the stereotype of the rule-following gate keeper of knowledge.

The image of the librarian in The Station Agent (2003) was the most positive characterization in all of the films. Finbar McBride (played by Peter Dinklage) is a man with dwarfism who inherits an old dis-used train station in a small town in New Jersey. He moves into the station and reluctantly befriends the quirky citizens of the town. The library scene takes place in the Newfoundland Library where Emily (played by Michelle Williams) is walking with a couple of books in her arms. The first thing that comes out of the librarian's mouth is a scream, because Fin's presence startles her: not what one would expect from the stereotypical shushing librarian. Also against type, she is young, wears her hair long and loose, and is in a tshirt and jeans. There are no glasses in sight. She is even wearing fashionable and decidedly unpragmatic heels. She is unmarried but has a boyfriend, smokes and is pregnant! There is a computer monitor in clear view on her desk. This is a real woman, warts and all. There is a wink to the stereotype in a line at the end of the movie. Fin's friends ask if he will date Emily. One says it is "the ultimate librarian fantasy: Glasses off, hair down, books flying." Fin says, "She doesn't wear glasses." The friend replies, "Buy her some, it's worth it" (Skalski, 2003). This humorous reference to the 
glasses, as part of the stereotype, underlines the fact that Emily does not represent the common stereotype.

We return to the prevalent image of the librarian in Because of Winn-Dixie (2005). This movie is about a lonely girl, Opal (played by AnnaSophia Robb), who tries to find friends in a new town. She ends up at the local library where the librarian, Miss Franny (played by Eva Marie Saint), is sleeping at her desk. She is in her 70s or 80s, has a bun, wears glasses and is sporting a high-collared dress. At first she says that Opal cannot bring her dog into the library, but then she relents and lets Opal break the rules. The librarian is very kind to Opal, befriending her and telling her a story about a bear that once broke into the library. Opal asks Miss Franny if she was ever married. The librarian replies, "I didn't have the need...I have these books" (Albert, 2004). There is no computer in the library. This movie librarian seems to have taken one of Wallace's suggestions on changing the librarian image: "Above all, be nice to those children" (1989, p.25)!

There is a small librarian scene in the film, I Love you, Beth Cooper (2009). This movie is about a group of students graduating from high school. The two male leads, Denis Cooverman (played by Paul Rust), and Rich Munsch (played by Jack Carpenter), are talking about their plans in the school library. The African-American librarian (un-credited, played by Natalie von Rotsburg) is seen in the background chatting with groups of students at tables. She looks to be in her 30s or 40s, short hair (no bun) and no glasses. She is dressed in a conservative suit, with pants and a blazer. The boys get shushed not once, but twice. After the second shush, one of the boys looks over to her and says, "Seriously?" (Barnathan, 2009). As the shot pans over the library, a group of computers can be seen at a study table. It is ironic that the library itself is presented as a more modern "learning commons" space, with computer stations and group study tables, and yet the librarian conforms to the stereotype by sternly shushing the boys - and she does it immediately after we see her chatting openly with a group of students!

The last movie of the modern set was Arthur (2011). The movie is about a spoiled wealthy layabout, Arthur (played by Russell Brand), who sees the error of his ways, gets sober, and tries to date the young author, Naomi Quinn (played by Greta Gerwig). At the end of the movie, Arthur finds himself at the New York Public Library listening to Naomi reading from her new book to a group of children. Throughout the scene, the librarian (un-credited, played by Pamela Holden Stewart) can be seen sitting at her desk, diligently working away. There is a computer monitor in front of her and another public terminal off to the side of the desk. The librarian appears to be in her 50s, with her hair up in a bun, high-collared blouse, and glasses. She does not have a speaking (or shushing!) part, so it is difficult to describe her characterization.

\section{Results}

The physical characteristics that have consistently been identified with librarians in movies are: (a) age, (b) hairstyle, (c) eyeglasses and (d) modest clothes (Tevis \& Tevis, 2005, p. 17). Of the six movies from the 1940s and 50s, all six featured librarians over 30 years old, with one of them including a 20 year old student assistant and one featuring a librarian in her 20s. Of the librarian characters in six films, five out of the six featured buns and one had short hair. Four of the six movies included librarians wearing glasses, and all six wore conservative clothes. Had anything about appearance changed in the movies from the 2000s? Four of the six modern films featured 
librarians over 30 years old. Three out of six librarian characters wore glasses. Five out of six emphasized conservative dress (see Figure 1 in Appendix).

As we have seen, librarians in film are often characterized as unmarried "spinsters." "Some women are portrayed as teachers, nurses, or librarians who, due to circumstance beyond their control, end up as spinsters" (Ferguson, 1991, p. 131). Of the 17 librarians in the 12 movies, 12 librarians were unmarried. The matrimonial state of the remaining librarians was unclear. In the modern movies, four out of six were unmarried, and two unknown. None of the 17 librarians were known to be married. In 2010, women comprised $47 \%$ of the United States labor force, and $58 \%$ of US women over the age of 16 were labor force participants (U.S.

Department of Labor, 2010). One would assume that with these facts of women's employment, we would see more representations of married librarians. As can be seen in Figure 1 (in Appendix), there has been little change in librarians' marital status depicted in movies.

When looking at these portrayals of movie librarians, one would hope that because the role of librarians has changed, as a result of new technologies and use of space, the characterization would also have changed. In five of the six movies from the 1940s and 50s, the librarian is stern or mousy. Only in Desk Set do we see librarians who are cheerful and witty. Of the six modern films, only in five was there sufficient conversation or even facial expression to describe their demeanor. Of those five, two librarians were stern, one was mousy, one was kind and one was a "normal" personality, i.e., no defining stereotypical traits (see Figure 1 in Appendix).

In the last 60 years we have seen the eradication of rubber stamps and card catalogues and the "growing development and widespread use of electronic information retrieval technologies in modern libraries" (Radford \& Radford, 1997, p. 251). One of the more contemporary themes analyzed when comparing the movies from each era was the use of computers. Obviously, the portrayal of computer use was not expected in the 1940s/50s movies, but there was full expectation of evidence of computers in the films from the 2000s. By including the computer in the library workplace, Desk Set was an anomaly. A surprising finding was that only three of the six modern movies used computers in the library setting. One would hope that, as the modern library has become a more dynamic gathering place and information hub, the perception of the role of the librarian will change and thereby filter into representations in the media.

\section{Combatting the Stereotype}

In comparing the movies from eras 60 years apart, we can observe whether or not any of the films fought the stereotypes by using the approaches outlined in the more recent studies: (a) reverse the stereotype, (b) substitute a range of positive images, or (c) contest from within, or "own" it (Adams, 2000; Duncan, 2004; Radford \& Radford, 2003; Wallace, 1989). Of the movies from the 1940s and 1950s, only two showed non-stereotypical representations of the librarian. Even though the young assistant librarian in the film Good News (1947) substitutes a range of positive images (fashionable clothes, no glasses, funny and personable), there is still a stereotype represented by the older, stern, shushing librarian. Although the librarians were unmarried in Desk Set (1957), it is the only movie studied from the earlier era that depicted 
overall positive characterizations of librarians. One could argue that because all the librarians in Desk Set (1957) were unmarried, they were not fully reversing the stereotype, even though the rest of their traits effectively reversed the usual portrayal. This paper would also suggest that the character of Bunny Watson actually "owns" the stereotype with her bun (complete with pencil sticking out) and her vast intellect; she obviously has fun exaggerating these traits, while also displaying traits that are the reverse of the prevalent image.

Of the modern era movies, it was found that only three of them combat the negative librarian stereotype, each in different ways. The substitution of positive images can be found in the Miss Franny character in Because of Winn-Dixie (2005). Although all of her physical traits conform to the stereotype, she is very kind and friendly to the young girl, Opal. We find the reversal of the stereotype in both Tomcats (2001) and The Station Agent (2003). The librarian in Tomcats is the typical librarian in her workplace, but then she morphs into a dominatrix at home. Not particularly a reversal of stereotype that furthers the cause! Also, because this "reversal" was not in her workplace, it could be argued that it is not a true reversal. Emily, the librarian in The Station Agent, is the only librarian among all 12 movies that truly is a reversal of the stereotype. Even though she is unmarried, she not only has a boyfriend but is also pregnant.

Every other aspect of her character is the "young, cool, and hip" (Radford \& Radford, 2003, p. 67) depiction that can be seen as a reversal of stereotype.

\section{Conclusion}

It is generally agreed that "Hollywood movies influence the public's thinking about the image of librarians... [and] by looking at Hollywood's treatment of librarians we discover indications of how the public views us" (Walker \& Lawson, 1993, p. 16). Throughout the last 60 years, with more and more women participating in the workforce and the lines between gender roles being blurred (Newmyer, 1976), one would assume that the pervasive negative stereotypes of female librarians found in movies from the mid- $20^{\text {th }}$ century would be mitigated in the $21^{\text {st }}$ century films. Moreover, with the surge of technology within the field of library science, the development of the internet, and the availability of websites that allow real librarians to present their own multi-faceted images to the world, one would expect the eradication of the negative stereotype (Stevens, 2001).

As the boomer generation retires in droves, "the image of librarians becomes even more important" (Peresie \& Alexander, 2005, p. 24). Who will want to become a librarian when bombarded with caricatures of the profession? It would be an interesting and important future study to replicate Form's 1946 survey, albeit with more standardized methods, to discover what people think of librarians now, and if the results align with the modern film depictions. Moreover, because the next generation of librarians will not only be at ease in the high-tech 
world, but will depend upon it, any future surveys should tap into teens and/or young adults' perceptions of librarians. As the results in this paper have shown, there really has been little change in the image of the librarian in movies in the last 60 years. There is some movement though with the inclusion of technology in library scenes and the characterization of a librarian as a fashionable, regular young woman, like Emily in The Station Agent (2003). As more of these progressive images are included in movies, the collective perception of the librarian will begin to change. The tired portrayal of the stern countenance, the bun and spectacles, will be replaced by a dynamic, engaging and real person... who just happens to be a librarian. 


\section{Appendix}

Figure 1: Comparison of librarian traits.

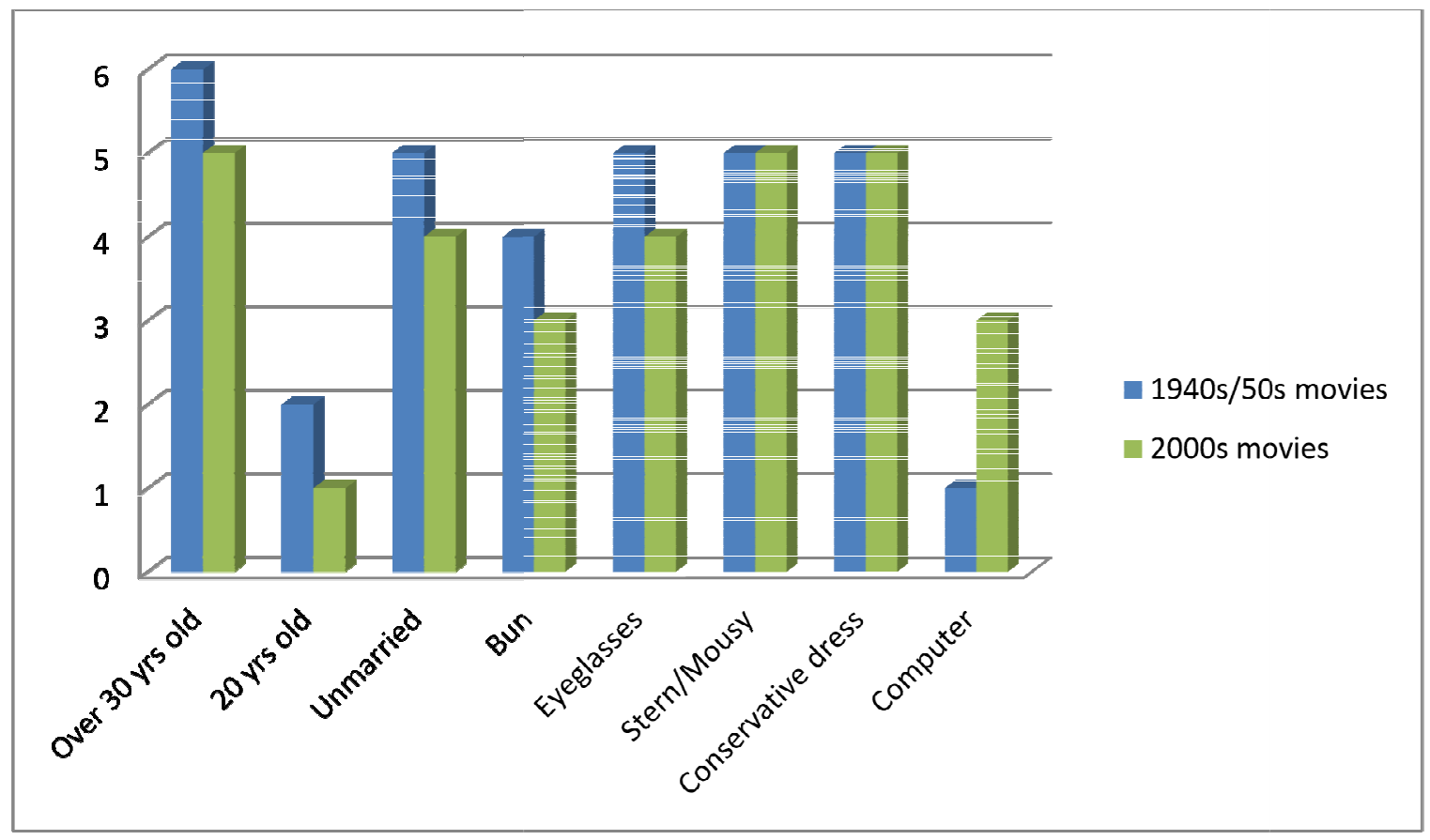

Figure 1. Comparison of stereotypical librarian characteristics found in six movies from the 1940s/50s and six movies from the 2000s. Each bar represents the number of movies in which these characteristics were found. 


\section{References}

Abraham, M. (Producer), \& Hoffman, M. (Director). (2002). The emperor's club [Motion picture]. U.S.A.: Universal Pictures.

Adams, K. (2000). Loveless frump as hip and sexy party girl: A reevaluation of the old-maid stereotype. Library Quarterly, 70(3), 287-301. doi:10.1086/603194

Albert, T. (Producer), \& Wang, W. (Director). (2005). Because of Winn-Dixie [Motion picture]. U.S.A.: $20^{\text {th }}$ Century Fox.

Barber, K. (Ed.). (1998). The Canadian Oxford Dictionary. Toronto, Ontario: Oxford University Press.

Barnathan, M. (Producer), \& Columbus, C. (Director). (2009). I love you, Beth Cooper [Motion picture]. U.S.A.: $20^{\text {th }}$ Century Fox.

Capra, F. (Producer), \& Capra, F. (Director). (1946). It's a wonderful life [Motion picture]. U.S.A.: RKO Radio Pictures, Inc.

Duncan, A. (2004). Caught between the stacks and a hard place: Dealing with librarian stereotypes. Louisiana Libraries, 66(4), 3-5. Retrieved from http://www.llaonline.org

Ephron, H. (Producer), \& Lang, W. (Director). (1957). Desk set [Motion picture]. U.S.A.: $20^{\text {th }}$ Century Fox.

Ferguson, S. (1991). The old maid stereotype in American film, 1938 to 1965. Film \& History, 21(4), 131-144. Retrieved from http://www.uwosh.edu/filmandhistory/

Freed, A. (Producer), \& Walters, C. (Director). (1947). Good news [Motion picture]. U.S.A.: Metro-Goldwyn-Mayer.

Garner, T. (Producer), \& Poirier, G. (Director). (2001). Tomcats [Motion picture]. U.S.A.: Sony Pictures Entertainment (SPE).

Form, W. (1946). Popular images of librarians. Library Journal, 71(1), 851-855. Retrieved from http://www.libraryjournal.com.libaccess.sjlibrary.org/

Jones, H. M. (1960). Reflections in a library. Saturday Review, 43, 34. Retrieved from http://www.unz.org/Pub/SaturdayRev-1960apr09-00034 
Leigh, R. \& Sewny, K. (1960). The popular image of the library and the librarian. Library Journal, 85(1), 2089-2091. Retrieved from http://www.libraryjournal.com.libaccess.sjlibrary.org/

Mankiewicz, J. L. (Producer), \& Cukor, G. (Director). (1940). The Philadelphia story [Motion picture]. U.S.A.: Warner Brothers Pictures, Inc.

Newmyer, J. (1976). The image problem of the librarian: Femininity and social control. The Journal of Library History, 11(1), 44-67. Retrieved from http://www.jstor.org/stable/25540671

Peresie, M. \& Alexander, L. B. (2005). Librarian stereotypes in young adult literature. Young Adult Library Services, 4(1), 24. Retrieved from http://www.ala.org/Content/NavigationMenu/YALSA/YALSA.htm

Powell, L. C. (1959). Librarians and their books. Saturday Review, 42, 17. Retrieved from http://www.unz.org/Pub/SaturdayRev-1959apr11-00017

Radford M. \& Radford, G. (1997). Power, knowledge, and fear: Feminism, Foucault, and the stereotype of the female librarian. Library Quarterly, 67(3), 250-266. doi:10.1086/629951

Radford M. \& Radford, G. (2003). Librarians and party girls: Cultural studies and the meaning of the librarian. Library Quarterly, 73(1), 54. doi:10.1086/603375

Skalski, M. J. (Producer), \& McCarthy, T. (Director). (2003). The station agent [Motion picture]. U.S.A.: Miramax Films.

Stevens, N. (2001). The last librarian. American Libraries, 32(9), 60-64. Retrieved from http://www.ala.org/alonline/index.html

Stout, N. (2004). Profession on the verge of a nervous breakdown. Serials Librarian, 47(1-2), 4555. doi:10.1300/J123v47n01-03

Tancheva, K. (2005). Recasting the debate: The sign of the library in popular culture. Libraries \& Culture, 40(4), 530-546. Retrieved from http://www.utexas.edu/utpress/

Tevis, R. \& Tevis, B. (2005). The image of librarians in cinema, 1917-1999. North Carolina, U.S.A.: McFarland \& Company, Inc.

Threatt, M. (2005). Bad to the bone, librarians in motion pictures: Is it an accurate portrayal? Indiana Libraries, 24(2), 6-9. Retrieved from http://www.ilfonline.org

U. S. Department of Labor. (2010). Women in the labor force in 2010. Retrieved from http://www.dol.gov/wb/factsheets/Qf-laborforce-10.htm

Walker, S. \& Lawson, V. L. (1993). The librarian stereotype and the movies. MC Journal: The Journal of the Academic Media Librarianship, 1(1), 16-28. Retrieved from http://wings.buffalo.edu/publications/mcjrnl/v1n1/image.html 
Wallace, L. (1989). The image - and what you can do about it in the year of the librarian. American Libraries, 20(1), 22-25. Retrieved from http://www.ala.org/alonline/index.html

Warner, J. L. (Producer), \& Hawkes, H. (Director). (1946). The big sleep [Motion picture]. U.S.A.: Warner Brothers Pictures, Inc.

Welles, O. (Producer), \& Welles, O. (Director). (1941). Citizen Kane [Motion picture]. U.S.A.: RKO Radio Pictures, Inc.

West, C. \& Katz, E. (1972). Revolting librarians. San Francisco, California: Booklegger Press. 